\title{
"What Value Should We Attach to All These Petitions?": Petition Campaigns and the Problem of Legitimacy in the Nineteenth-Century Netherlands
}

\author{
Maartje Janse
}

This article focuses on large-scale petitioning campaigns, or petitionnementen as they were called, organized between 1828 and 1878, including contemporary reflections and debates on this new phenomenon. Although there were only a handful of petitionnementen, they had a remarkable impact-not only on the issues at hand but also on the balance of power between Crown, Cabinet, Parliament, and people. Mass petitions necessarily challenged the political system, whose legitimacy was based on elections under a limited franchise. Based on parliamentary reports, pamphlets, and other sources reflecting on petitioning in general and the petitionnementen more specifically, this article asks how petitioners claimed legitimacy, and how politicians and other observers responded to those claims. Special attention is given to the international context within which Dutch petitioning practices developed. The article focuses on three case studies, representing the major petitioning campaigns of this period: the Southern petition movements of 1828-1830 that were a catalyst for the Belgian revolution (thus reinforcing the association between mass petitioning and revolution), the Anti-Catholic "April Movement" of 1853, and the so-called People's Petitionnement of 1878, against the liberal education law. Remarkably enough, in the Netherlands it was not progressive reformers, but most prominently conservative Orthodox Protestants who organized petitionnementen.

In the nineteenth century, several large-scale petition campaigns were organized in the Netherlands. This was a highly contested phenomenon. The response by government, Parliament, and citizens indicates that fundamental issues were at stake. The central question was: To what extent could ordinary citizens participate in the political system (Talsma 1989: 42)? The question of the legitimacy of popular participation through petitioning was further complicated by the constitutional system after 1815. The political system facilitated popular representation through elections under a restricted franchise, but the legitimacy of expressions of the voice of the people through nonelectoral mechanisms was subject to debate. Questions of legitimacy, who could and should petition, to which authority, and how authority should regard mass petitions, were central to nineteenth-century political culture in the Netherlands. This article offers an analysis of the nineteenth-century debate about these newly emerging practices of petitioning.

The history of petitioning in the Netherlands warrants scholarly attention and contributes to the wider understanding of the emergence of mass petitioning in different national contexts in the long nineteenth century, which is the focus of this special issue. Dutch political historians have discussed petitions within studies of 
political change, and there are some studies of particular campaigns (François 1992; Houkes 2002; Ramakers 1990), but aside from Talsma $(1979,1989)$ little has been written on petitioning. The exception is a recent article by Joris Oddens on the debates over petitioning between 1750 and 1830 (Oddens 2017). The right of petition was self-evident from the days of the Dutch Republic, but there was a long tradition of debating who was eligible to petition, especially on public or political issues. During the Patriot Era of the 1780s, reformist citizens challenged the ruling coalition, leading to a "petitioning craze" and a wider debate on the legitimacy of political petitions (ibid.).

Throughout the various regimes of the 1795-1813 period, the right of petition was guaranteed by all respective constitutions. The right was not mentioned, however, in the new constitution of the Kingdom of the United Netherlands, drafted in 1814. The right to petition was recognized, but the constitutional committee feared that drawing attention to it would encourage petitioners in a system in which sovereignty resided with the king rather than the people. Furthermore, the Second Chamber of the bicameral Parliament was elected indirectly by the members of the Provincial Councils, who in turn were elected by a small percentage of the population. Widely signed petitions, then, could claim to be more representative of the people than their representatives, raising questions of legitimacy and how politicians should respond to popular participation.

This article can be read as a sequel to Oddens's essay. It outlines the history of petition campaigns in the Netherlands between 1828 and 1878, especially those on national political issues. In this period three major mass petitions were organized, which stimulated a broad discussion about the merits and perils of large-scale petitioning. Based on parliamentary reports, pamphlets, and other sources reflecting on this phenomenon, this article asks how petitioners claimed legitimacy, and how politicians and other observers responded to those claims. Although there were only a handful of mass petitions, they had a remarkable impact—not only on the issues at hand but also on the balance of power between Crown, Cabinet, Parliament, and people. Directly or indirectly, petitions led to revolution and Belgian independence, the fall of at least two governments, the establishment of the first political association under the constitutional system (the Amstelsociëteit), and the first political party in the Netherlands (the Anti-Revolutionary Party).

A mass petition is here defined as the product of an organized petition campaign, often containing thousands of signatures, either combined in one petition, or several separate petitions. Contemporaries used address, request, and petition interchangeably, and did not use the term mass petition. The phrase "monster petition" was used only once in parliamentary debates before 1892 (Handelingen June 17, 1877: 947). As in other countries, such as Spain, the emergence of new, mass forms of petitioning in the nineteenth century led to new words being coined to describe them (Palacios Cerezales, 2019). In the Netherlands, the term petitionnement was used to describe large-scale petitions. Derived from the French word pétitionnement, used by the French-speaking Belgians for their petition campaigns of the late 1820 s, it was adopted by Dutch-speaking representatives and commentators around the same time. 
Significantly, pétitionnement literally meant "the action of petitioning," describing the new phenomena of organized mass-petition campaigns, and indicating that this was a major departure from earlier practice.

The petitions of the late 1820 s were not the first mass petitions to be organized in the Netherlands. However, after 1815 politicians and public sought to distance themselves from the revolutionary era (Oddens 2017). This explains the fact that the first national large-scale petitions from the eighteenth century were rarely mentioned in the nineteenth century. The most impressive petition campaign was organized in 1797 by the Dutch Reformed Church to protest at the loss of its privileged position. The campaign attracted the signatures of 215,000 people out of a total population of less than two million (Den Ouden 1994: 131-43; Kompagnie 1985; see Oddens and Turpijn 2010: 26 for another example).

However, while organized petition campaigns were associated with revolutionary politics until at least 1840 , thereafter they gradually became a part of regular political life. The Dutch case highlights two general trends in the nineteenth century that can be seen as well in Britain, the United States, Spain, and colonial India: the rise of petitioning on political or public issues, and the development of organized, singleissue, mass-petition campaigns (Carpenter and Topich 2015; Jaffe, 2019; Miller 2017; Palacios Cerezales, 2019). These developments were highly contested in the Netherlands as elsewhere, not least because they were often thought of as "foreign." This article does not compare the history of Dutch petitioning to that of other countries. Still, in an attempt to open up perspectives on national political history, it places (reflections on) Dutch petitioning practices within their transnational context. It does so by tracing how new practices, or criticism thereof, were inspired by political developments beyond the Dutch border.

This article argues that while petition campaigns became more common and professionalized, the legitimacy of the petitions brought forth by these campaigns was often questioned within a political system based on the idea of popular representation through elections. Even so, from the $1850 \mathrm{~s}$, and especially from the 1870 s, petitions were increasingly used and, according to critics, often abused.

\section{The Southern Petition Movements, 1828-1830}

In the Netherlands, petitioning and organized, large-scale signature gathering had long been associated with revolution. Political opposition and criticism became problematic during the increasingly autocratic rule of King Willem I (1815-40) (Van Zanten 2004). Most people believed that mass petitions would lead to revolution, though others claimed they prevent such upheaval by acting as a safety valve to express public grievances (Talsma 1989: 32).

Discontent with Willem I's policies swelled in the largely Catholic Southern Netherlands where he pushed through an ambitious agenda of cultural unification. Attempts to curtail the power of the Catholic Church and to suppress the freedom of the press resulted in a remarkable Union of Opposition for the redress of grievances, 
consisting of Catholics and Liberals (Koch 2013: 430-34). They expressed their grievances in two huge waves of petitions: the first, presented in March 1829, consisted of 150 petitions with around 50,000 signatures (François 1992).

The petition movement sought to influence the impending parliamentary debates on the 10-year national budget in May 1829 and was partly stimulated by the incarceration of critical journalist Louis de Potter (Koch 2013: 432-33; Ramakers 1990: 204). Transnational currents also shaped mass-petitioning practice. The late 1820s experienced a global freedom struggle. Simon Bolivár's independence campaigns in South America and Greece's fight against the Ottomans strengthened the notion that change was possible. This optimistic belief in progressive change and reform was given further credence by the movement for Catholic rights in Britain, and the campaigns to end slavery in Britain and the United States in the late 1820s (also see McDaniel 2013: 34-43). The example of the mass-petitioning campaign of the Catholic Association in Ireland seems to have strongly influenced the Southern petition movements. In February 1829, the British public was reeling from the "thunderclap": the news that the government would introduce Catholic Emancipation, meaning that Catholics could hold public offices, including being elected to Parliament (O'Ferrall 1985: 239-42).

There are at least two elements in the Southern petition movements that were strongly reminiscent of the Irish campaigns for Catholic Emancipation. Firstly, as in Ireland, the clergy played a central role in organizing the campaigns, especially in Flanders (Ramakers 1990: 204). Secondly, and following the practice of the Irish campaign, the organizers cunningly combined their own grievances with other grievances that were shared by the broader populace, especially the lower middle classes and working classes, including the mill tax (ibid.: 206), in single petitions. Willem I's biographer Jeroen Koch expresses puzzlement over the use of the word grievances and connects it to the American Constitution (Koch 2013: 434, 649). While that may have been an important inspiration, it seems more likely that the omnipresent use of the word came from its programmatic use by Irish advocates of Catholic Emancipation, which was almost certainly familiar to Belgian Catholics through the press and personal networks.

The Irish lawyer Daniel O'Connell had recognized in 1823 the power of the local grievance as a means of mass mobilization. Thereafter, he politicized every issue by calling it a grievance and promised the Irish Catholics that if they supported the Catholic Association, total redress of all their grievances was within reach (O'Ferrall 1985: 37-39). As in the case of the petitions of the Irish Catholic Association, and later those of the British Anti-Corn Law League, the Southern petitions summarized a broad range of long-standing grievances, turning their petitions into a concise political program that could mobilize a broad coalition. In that sense petitions, single-issue organizations and political parties functioned similarly: all urged people to add their voices to the choir that sang their particular chorus as loudly as possible — either through signing, membership, or voting (Janse and Te Velde 2017).

Van Maanen, the repressive minister of justice, was worried about the petition movement, and the lack of available legal actions to prevent it due to the 
constitutional status of the right to petition. He wrote to Willem I, agreeing that these petitions threatened public order and the stability of government. The petitions were "of the most exorbitant nature," and the movements were "fully conceived to rouse the passions of the very lowest class of citizens, and malevolent demagogues could easily move the dregs of the people to sign them" (Colenbrander 1905, II: 546). Despite privately questioning the legitimacy of the petitioners and the movement, Van Maanen reluctantly informed the king that there was no legal ground on which to suppress the campaign. "Massively signed petitions ... have been tolerated for too long" and had become part of customary law, he wrote. However, he distinguished the usual type of large-scale petitions, which made sectional demands on behalf of "specific interests," such as particular trades, social groups, or localities, from the new type of mass petitions. Never before, he claimed, had such petitions focused on "general state interests, principles of government, questions of constitutional law etc.; never before have they been accompanied by public invitations to sign, nor have they been placed, to that end, in public places ... [nor] presented for signature to the houses of citizens by servants"' (ibid.: 545). Although he was powerless to prevent it, Van Maanen's comments are revealing of the anxieties of political authority confronted by the new form of mass petitioning.

Willem I, worried about the political character of the protests, decided to tour the Southern Netherlands. During a speech at Liège, the king made some derogatory remarks about the petitions, which immediately rekindled deep-seated feelings of resentment. Willem I told the crowd that he realized that the petitions had been driven by a few individuals with their own personal agendas, so he did not take the "false grievances" seriously. He accused the petitioners of "infamous conduct" (Koch 2013: 438-43). Some of his critics, seizing the moment, immediately formed an "Order of Infamy" (motto: "Loyal Unto Infamy") and started a second petition campaign, even larger than the first, indicating increased organizational effectiveness (ibid.: 443-44; Ramakers 1990: 209-11).

The second wave, in October 1829, consisted of 1,000 petitions signed by more than 300,000 citizens. They were not all from the future Belgian provinces. Ramakers (1990) has documented a modest but remarkable petition movement in the southern part of the Northern Netherlands (also see Van Sas [1982] 2004). The public nature of petitioning lowered the threshold for protest considerably, and encouraged greater political participation. Publicity increased the scale of the petitioning movement and the volume of signatures, included those of women and children. Ramakers (1990) shows that many petitions were representative of their local social structure. The petition from Bergen (currently Dutch Limburg) gathered 597 signatures, 17 percent of the inhabitants. Forty percent of the signatories were female, and many were children, among them three 10-year-old boys (Ramakers 1990: 216).

The king was furious at the wave of petitions aimed against his policies and governing style (Koch 2013: 444). The petitions stimulated a wider debate in Parliament and outside on their legitimacy. In his lengthy pamphlet, The Unlawfulness of Petitions to the Estates-General, the conservative jurist Cornelis van Assen argued that the scale of petitions would damage parliamentary efficiency 
(Van Assen 1829: 127). Other representatives, employing a critique often used by opponents of mass petitions in many countries, questioned the legitimacy of organized petition campaigns, and dismissed them as the product of demagoguery and manipulation by agitators. The role of Catholic priests was singled out for special criticism (Ramakers 1990: 222). The practices associated with the petitioning campaigns were used to discredit the petitions. "Anonymus Gelrus" complained about these "libellous petitions ... often in the form of we demand etc ... of which it is known that they are presented in pubs and common taverns, to make the commoners sign them for a reward in the form of a drink." The fact that children and other "senseless" citizens such as women signed these petitions delegitimized them (Gelrus 1830: 56, 51). These types of criticisms were by no means new and echo the late-eighteenth-century consensus that legitimate petitions should be humble, strictly necessary so as not to waste Parliament's time, and the result of a voluntary act rather than inducement or manipulation (Oddens 2017: 637).

However, the scale of this petition campaign, and the fundamental questions it raised about the relationship between government and the people, made it impossible to simply dismiss them. The scale of popular participation raised questions of legitimacy about the current political system, as the petitions confronted the legislature with a broader constituency than that which elected Parliament. Mass petitions could with some justice claim to be more representative and legitimate than Parliament. Unsurprisingly perhaps, representatives did not question their own legitimacy but instead focused on the dangerous consequences of allowing these claims to be made.

The high level of popular participation stimulated by the petition campaigns would lead to chaos, many argued. One anonymous critic stressed that petitions on issues of constitutional law should "in all instances remain completely beyond the competence of the masses ... so that the people will never interfere with the national government, or consider itself qualified to have a voice in the legislative process... [T] hat way our constitutional and limited Monarchy would soon degenerate into a sort of Democracy" (Anon. 1830: 99-102). Van Maanen voiced similar concerns when he wrote Willem I that this "petition frenzy," if unchecked, could "lead to the state of democracy, of anarchy even" (Talsma 1989: 37; Colenbrander 1905, II: 545). Representative J. C. van de Kasteele pointed out that the "opinion of the masses" should not be conflated with respectable "public opinion." He was unimpressed with the size of the petitions: the number of signatories was "insignificant" in comparison with the total population, and consisted mostly of the "lowest classes of inhabitants." Denying these petitions represented public opinion was important in keeping popular sovereignty at bay (Talsma 1989: 30, 31).

Not only did these mass petitions raise the specter of popular sovereignty and democracy, they were also believed to lead to national discord and even revolution. Anonymus Gelrus thought the situation severe enough to invoke the memories of the revolutionary past, warning: "What is this, but threatening public order, sowing the seeds of discord, and cultivate chaos and disruption? What is this, but renewing the years of 1784-1787, when [the press also tried] to agitate the people?" 
(Gelrus 1830: 51-52). Most attempts at delegitimizing these petitioning practices claimed that mass petitioning was contrary to the Dutch national character and an imported practice. The right of petition, a critic argued, was a fruit of the French revolution, "unripe and tart, because it never flourished on French ground." After the revolutionary period, the calm tenor of the Dutch had resurfaced, and the people had looked back with embarrassment on their revolutionary behavior (Van Assen 1829: 86, 102-3). Now he blamed the English for the return of un-Dutch politics. "From that England, whence the madness of continental nations has brought back so many institutions, without considering, like a botanist who wants to transplant foreign plants, that the condition of the soil stands in direct relation to the fruits it bears. It would be worth investigating, how much harm has been done to other nations by that incautious imitation of the English, that we may call anglomania" (ibid.: 60-61).

Some liberal representatives disagreed that mass petitions would lead to revolution, arguing instead that petitions could channel criticism and thus prevent sudden eruptions of discontent (Talsma 1989: 32). They believed that if well-regulated, popular participation could become a fruitful means of communication between government and governed, and a source of popular legitimacy for Parliament and the political system. In this vein, L. C. Luzac wrote to Van Assen in 1829: "We need representatives who understand that a constitution should bring life to all parts of the body politic, and that this life is not insurrection, but necessary movement and progress in the right direction" (Van Zanten 2004: 260).

The question of political legitimacy, both of the recipient authority and the petitioners, was debated at length. Most of the Southern petitions were addressed to the House of Representatives. This had controversial implications: when the 1815 constitution of the United Kingdom of the Netherlands was presented, Van Maanen had stressed that petitions should be sent to the king through the Provincial Councils, bypassing Parliament (Talsma 1989: 21-23). This understanding was confirmed by a Royal Decree in 1820, which prevented the Heads of Departments from accepting any information but laws directly from Parliament (ibid.: 27). The practical as well as political question raised by the Southern petitions in 1829-30 was what to do with these documents addressed to Parliament, rather than the king as was the constitutional procedure.

Several representatives defended the right of inhabitants to petition them directly, partly because it strengthened their legitimacy as representatives of the people by signaling public trust. Some, like Luzac, argued that the House of Representatives should be an intermediary power between citizens and government (ibid.: 32). In 1829 the House of Representatives came up with a creative solution to the question and sent a formal address to the king-essentially petitioning the king themselves to draw his attention to the petitions they received-but this was voted down by the Senate (ibid.: 31).

The king and cabinet ministers feared that representatives forwarding petitions to the government would set a bad precedent that would legitimize and normalize petitioning Parliament, but it would also lead to ministerial responsibility, which they resisted (ibid.: 36). It was no coincidence that ministerial responsibility, the doctrine 
that cabinet ministers are responsible for their policies and must be answerable to Parliament rather than the king, was one of the demands of many Southern petitions, further politicizing the question how to handle the petitions (Van Velzen 2005, especially 301-4).

On August 25, 1830 a revolution broke out in Brussels that would lead to Belgian independence, although it took Willem I another decade to accept this fact. The revolution seemed to justify the fears that mass petitions could foment political passions that had the potential to break up the state.

\section{Toward a Liberal Constitution}

The reign of Willem II (1840-49) expanded room for criticism and opposition, which led, as elsewhere in Europe at the time, to the development of a liberal movement (Aerts 1997). The liberal law professor Johan Rudolph Thorbecke detailed his reform ideas based on the notion that the age was moving toward more widespread political participation. He wrote, "[T]he relation of the most elevated individual, elevated by nature or by rank and power, to the whole and to the mass, has become more natural. His rank is not as high, the privilege that he enjoyed to represent his time or people ... is confined more and more narrowly." Eventually, general suffrage would be unavoidable, he claimed (Thorbecke [1844] 1872: 90; for more on Thorbecke's ideas see Aerts 2018).

In 1844 Thorbecke, together with eight other liberals, proposed a bill for a fully revised constitution, including ministerial responsibility, direct elections for the Second Chamber, and annual budgets. The "nine men" as they were known, knew the bill had little chance of success at this time. The bill was really a manifesto aiming to mobilize public opinion in favor of liberal ideas (Van Sas [1998] 2004: 472-73). The liberal press campaigned in support of the "Nine Men Proposal." One newspaper put it thus: "Let the King find out that the nine representatives truly speak for the nation" (Van Zanten 2013: 488). Petitions would reinforce this message. In a pamphlet dramatically titled Now or Never, some supporters called for petitions, followed by a model petition that required filling out only name and location. In Amsterdam, 500 copies of this model petition were placed in coffeehouses, stores, and taverns. The campaign led to the establishment of the first political association since the Revolutionary era: the Amstelsociëteit, a club where young liberals would meet to discuss strategies for cultural and political reform, but that also had success as an electoral association (Anon. 1845; Van Sas [1998] 2004: 474; Von Santen 1979).

Perhaps discouraged by the threats from provincial and local authorities that signing the petition could lead to prosecution or dismissal, only some 5,000 signatures were attached to the petitions supporting constitutional change, while a further 700 signed supporting addresses (Van Sas 2004 [1998]: 472-76; Van Zanten 2013: 485). Still, the Nine Men, as they became known, presented these petitions in Parliament as proof that they truly represented the nation, despite their lack of parliamentary support, implicitly questioning the legitimacy of their fellow 
representatives. They placed further emphasis on the numbers signing the petitions. One of them refreshed the memory of the members of Parliament (MPs) regarding the formal acceptance of the constitution in the Southern Netherlands in 1814. The majority of an ad-hoc body of Southern notables had voted against the constitution, but through dubious and highly contested "Dutch arithmetic" some of these votes were counted as votes in favor of the constitution, which had reduced its legitimacy in the South from the start. In the recent past, the voice of no more than 653 notables had been deemed sufficient support for a new constitution, so the voice of more than 5,000 notable citizens was more than enough to justify constitutional change now, he argued. As well as noting the numbers signing the petitions, the representative emphasized the quality of the petitioners. He went out of his way to prove that the petitioners were indeed "notables," who were members of the "best classes of society, the most well-to-do, the most respectable." All of them possessed the right to vote, and were perfectly capable of understanding the effects of the measure (Handelingen May 26, 1845: 428).

While liberals grounded the legitimacy of their demands in the number of petitions and quality of the petitioners, their opponents took a very different view of the petition movement. The Catholic jurist Mutsaers thought the "so-called petitionnement" was the surest characteristic of extreme passion and partisanship in politics (Handelingen November 11, 1844: 84). Willem II was very annoyed with the petition campaign and the Nine Men Proposal, even after it was voted down in Parliament (Van Zanten 2013: 486, 495-96). It was only in the wake of the European revolutions of 1848 that the Monarch realized the only way to safeguard his position now was to "seduce the masses" - "the masses are everything" (Koch 2013: 534, 380). Taking the initiative, he asked Thorbecke to draft a new, liberal, constitution, which would be based to a great extent on the 1844 proposal (Van Sas [1998] 2004: 460-61). A new era in Dutch politics had begun, one in which citizens could play an expanded role, although suffrage rights were not immediately extended. In 1848 and 1849, at least 2,000 petitions were sent to Parliament, demanding a wide range of policy changes, including electoral reform and tax reform (Talsma 1979: 440-42). However, it was not until 1853 that a petition movement on a truly massive scale was organized.

\section{The Aprilbeweging of 1853}

In April 1853, a strong anti-Catholic agitation, later known as the "Aprilbeweging" (April Movement), broke out among Orthodox Protestants over the plans to reinstate the Catholic hierarchy, a freedom the liberal government had to grant under the 1848 constitution. The movement also exploited lingering conservative resentment against Thorbecke. A national mass petition to the king was initiated from Utrecht by a handful of conservatives in cooperation with prominent members of the Dutch Reformed Church (the former state church). By distributing their local petition to all other Reformed church councils, who circulated it further among various religious 
networks and other denominational councils-it received more than 200,000 signatures, out of a total population of 3 million (Houkes 2002: 95). The Aprilbeweging was significant not only for its scale but also for showing that organized mass petitioning was a tactic that could be used by conservative religious groups as well as liberals. The petitions raised familiar questions about legitimacy, but representatives found their roles reversed from earlier debates as liberals questioned and conservatives defended the legitimacy of the petitioners and their campaign.

Although the movement failed to prevent the reinstatement of the Catholic hierarchy, it had serious political repercussions. When a delegation of the Amsterdam church council personally presented their local petition, signed by 50,000 men and women, to the young Willem III (who had succeeded as king in 1849), the monarch ignored the formal response his cabinet ministers had prepared for him. Expressing sympathy with the petitioners, the king proceeded to criticize his ministers and the constitution, leading to Thorbecke and other ministers to offer their resignations (ibid.: 97; Van der Meulen 2013: 271-76). Unsurprisingly, the Aprilbeweging was heavily criticized in liberal journal De Gids for its "passion, inappropriate threats, [and] insubordinate language." Ironically deploying criticisms used against earlier liberal petition campaigns, the journal argued that the Aprilbeweging was illegitimate as it had not been a "mouvement spontané" (spontaneous grassroots movement), but was the product of agitation and organization from above. "The driving forces behind it had, assisted by local ministers and antipapist fearmongering, put the inexpert popular masses up to signing requests that were themselves unconstitutional, as they did not respect the rights granted to Catholics in the constitution" (Koorders 1854: $33,22-23,38-39,328-46)$.

More surprising is that participants in the Aprilbeweging seemed to have agreed to some extent with this criticism. Soon afterward they downplayed the Aprilbeweging and their role in it (ibid.: 340-42). A year later antipapist journal De Fakkel wrote: "What has become of the Aprilbeweging? It is a faint, sad memory, an echo that died out long ago, a ridiculous thing" (De Rooy 2015: 75). Or, as a liberal put it mockingly in a parliamentary lecture: "First it was a national movement, after that it was just a movement spontané; now themovement spontané is appeased, and finally it will become clear to all the world that it was an inappropriate political movement" (Handelingen December 1, 1855: 264).

In subsequent decades, the Aprilbeweging was rarely mentioned in a positive way. While conservatives and religious groups could make use of mass-petition tactics, it seems that at this stage they were uncomfortable in doing so. This ambivalence is revealed in the views of the antirevolutionary parliamentary leader Guillaume Groen van Prinsterer on mass petitions. He had supported the Aprilbeweging, but in 182830 , as a young royal secretary to Willem I, he had witnessed firsthand the powerful effects of the petition campaigns and the Belgian revolution (Koch 2013: 439-44). When Orthodox Protestants wanted to organize another nationwide petition campaign against education reforms in 1855 , Groen advised them that the time was not ripe. "We are expecting, and looking forward to, the petitions of experts; but we deem that it is not time yet for a general petitionnement." Instead he advised them to 
"popularize the question" through spreading information "so that later the signing of the petitions will have gained more significance and strength" (Groen 1856a: 11-12).

\section{Quantity over Quality?}

Representatives were often ambivalent about mass petitions, with many preferring to judge the significance of a petition by the quality rather than the quantity of its signatures. "What value should we attach to all these petitions?," the liberal MP W. A. Viruly Verbrugge asked in 1865 about petitions on the sugar tax. "Have they all been signed by interested parties and experts," or had others, with ulterior motives perhaps, signed as well? For these reasons, Viruly proudly stated that "I do not ask how many signatures are placed under a petition, I only pay attention to the arguments.... I am not afraid of those petitionnementen; I only ask about the issues in the address and not about the number of signatures. This may have an effect on some, but does not further the case" (Handelingen May 5, 1865: 824). This was the typical, almost ritual declaration of independence from pressure from without that MPs had been offering for decades when they discussed petitions (also see Handelingen March 16, 1833, 205; August 9, 1848: 598).

However, petitions were valued as an indication of public opinion that, from the 1840 s, increasingly gained importance in political affairs. Before the $1880 \mathrm{~s}$, representatives were supposed to be selected based on the trust voters had in their character and their independent judgment. According to the "politics of deference," a candidate's opinion on specific issues was not supposed to play a role during elections. Public debates on issues should be conducted outside of elections through the exchange of arguments between the enlightened part of the public (Janse 2007; Manin 1997: 204-5). Public opinion, "understood as that of the most reasonable, virtuous, capable, and noble in the land," was taken seriously, and the idea that critical citizens and government could and should cooperate to promote the general good gained a foothold (Janse 2007: 147; 2011). In this new climate, the presence or absence of petitions on an issue took on additional significance. Ministers would defend their decision not to introduce a bill by "disparagingly mentioning," as one MP put it, that "there has only been one address about this issue" (Handelingen June 29, 1867: 1349). In 1851, during the debates on the new Education Law, Groen was told that the time was not ripe for his proposals because among the many petitions "recently no petition has been received relating to this subject." Action could be taken only "when it has been proven that the nation shares in your feeling" (Groen 1856a: 4).

The argument that the absence of petitions delegitimized policy change could be turned around to use the volume of petitions as a reason for new measures. Five years later, more than 100 petitions with around 13,500 signatures had been presented to Parliament as part of the complex and long-standing School Struggle. Liberals supported "neutral" religious education that promoted Christian values, but had banned dogmatic religious education in state schools. For this reason many Orthodox 
Protestants and Catholics funded denominational schools and demanded equal recognition for their schools, including subsidies. Returning to his earlier remarks, Groen urged his fellow MPs not to ignore these petitions. Ignoring them would make "the right of petition an almost ridiculous formality," and ultimately weaken the position of Parliament. He complained that most petitioners had tried to channel the stream of petitions to the king instead of Parliament: "“What can be expected', many said, 'of Parliament! It does whatever the cabinet desires; it does not pay attention to your wishes; it does not know them; it repudiates them. Has it ever done anything, to justify expecting even the least of concessions to your Christian and national desires? No! not to Parliament, address the King!"' Groen opposed this, arguing that the king should be a last resort for citizens, whereas petitioning Parliament was the regular and constitutional way for citizens to express their concerns (ibid.: 2, 16-17). Discarding the petitions would destroy what little trust remained in Parliament, he argued. Ominously referring to the consequences of the Aprilbeweging, including the resignation of the liberal cabinet, Groen warned that the current conservative government should not repeat the mistake of their opponents (ibid.: 16).

The conservative MP Johannes Bosscha voiced the opinion of the majority of MPs when he denounced the petition campaign as a dangerous threat to Parliament's independence and reputation. If Parliament allowed itself to be influenced by a petitionnement, counter-petitionnements by those who previously trusted the independence of Parliament would be the result. Parliament should be self-confident in its own judgment, rather than become "a plaything, tossed around by the opinions of all kinds of known and unknown petitioners" (ibid.: 25). Where Groen presented the number of petitions and signatures as indications that they represented the people's will, Bosscha agreed with others that the scale of petitions discredited their legitimacy. The campaign was a "demonstration of military forces," "an attempt to frighten and intimidate," and "the way an army parades around before battle." He was confident that the representatives would not change their convictions upon seeing "those heaps and hundreds of petitions." Why not? Because they would realize that the majority of the signatories did not really understand what they had signed. They had been told that this was a subject that "the simplest mind could judge. And therefore, whether the list of signatures cover one, or two, or twenty sheets or ells of paper, does not make a difference in my opinion" (ibid.: 21-24).

Because of its scale Groen had explicitly labeled the petition campaign a "petitionnement," which stimulated reflection on the nature of mass petitioning. "We do not just have petitions," Groen explained, "but also (I use a word that is known both favourably and unfavourably) a petitionnement. This means: already the multitudinous nature of the petitions proves that the measure that is protested, has produced an extraordinary measure of aversion and moral resistance." Bosscha, however, despised the phenomenon: "as much as I do respect the right of petition, so little do I respect a petitionnement" (ibid.: 52, 24). For him and most other MPs, a petitionnement did not represent the will of the people, but was rather the product of 
manipulative agitators and represented an illegitimate attempt to influence the true representatives of the people.

Willem III, however, was pleased with the petitionnement. Since the Aprilbeweging, he regarded himself the defender of the Protestant nation. Again, he supported the petitioners, and again used this as a pretext to break up a government that no longer pleased him (Van der Meulen 2013: 331). In this sense the fears that largescale petition campaigns could be employed as political weapons by political actors seem to be justified to a certain extent. In 1856 a liberal minister wrote to Thorbecke (MP at that time) that he still feared a new Aprilbeweging could be organized, "a machine de guerre constructed against you, that with the support of minsters of the church could have dangerous consequences. It is a strong example of the vulgarity of means employed by political hatred" (ibid.: 337).

A recurring criticism of large-scale petitions was that they were the product of "incompetent people, fallen victim to political trickery" (Groen 1856a: 57). Groen argued instead, that the constitution of 1848 had made it possible to inform the people about specific political questions. A decade later he stated in an oft-quoted sentence that agitation was nothing more than "using the right to vote, after studying and popularizing of the question, all the while learning what happens within parliament" (Houkes 2009: 198). The general opinion was that agitation would produce artificial expressions of the popular will and falsely represented public opinion. Groen was ambivalent about agitation-he had built his political ideas on a sound rejection of anything to do with the French Revolution. Yet he thought the contempt for agitation strange in the context of a constitutional government. Many representatives underestimated the people, he felt. He defended agitation by citing British liberal politician Macaulay's famous remark "what is agitation but the mode in which the public, the body which we represent, the great outer assembly, if I may so speak, holds its debates?" (Groen 1856a: 13-14, 93).

The elections of 1856 after the fall of the cabinet raised the stakes on the debate on agitation and what was legitimate public participation and engagement with Parliament. Groen published a series of short political pamphlets that were considered a novelty and were criticized. "You have been too inflammatory during this session.... Why ... this encouraging of Petitions and the like?" His countrymen disliked his approach, and Groen listed some of their responses: "It is too curious, it is too strange. The national character does not want anything outside of the ordinary. The path of sauntering and routine is the safe road to travel. Leave for England with your pamphlets. They reek of Anglomania." He replied, "I have never desired playing English Parliament; however, I do desire candid and open treatment of the public cause ... for this, I feel, something can be learned from the example of England" (Groen 1856b: 3-5).

Many liberals could agree with Groen on this point. Groen and Thorbecke were opponents, but their views on good politics could overlap (Te Velde 2002: 32-43). However, liberals were alarmed when Groen stated that Parliament should not underestimate the power of the "people behind the voters" and pointed out the revolutionary implications of this idea. Thorbecke accused Groen of "using the 
methods of revolutionary men, from which so many disasters of revolution has sprung" (Handelingen, September 26, 1856, 50). A liberal newspaper denounced the "popular frenzy, started and exploited by revolutionaries," who call themselves antirevolutionary, and attempted to discredit this petitionnement by comparing it to the Aprilbeweging (Arnhemsche Courant 1856; Houkes 2009: 189-90).

\section{Single-Issue Organizations and Petitions}

During the third quarter of the century, a new type of large-scale petitioning became more common: petition campaigns for reform organized by single-issue organizations. These campaigns were the backbone of famous British reform movements against slavery and the Corn Laws, as Dutch reformers were well aware (Janse 2005). However, they felt that the political context of the Netherlands was fundamentally different from that in Britain, and British-style mass petitioning would hinder rather than help the cause (Janse 2015). During the early 1840s, British abolitionists of the British and Foreign Anti-Slavery Society tried to actively influence Dutch petitioning practices. Their agents visited the Netherlands several times, attempting to export antislavery information and arguments but also the specific methods their movement had used to battle slavery, specifically large-scale public meetings, mass petitions, and an elaborate organizational structure to mobilize people and raise funds. The main problem the British faced in the Netherlands, they felt, was that the Dutch were unfamiliar with "the English apparatus of public meetings, petitions etc." (ibid.; Hodacs 2003: 113).

Liberals and Orthodox Protestants could not agree to collaborate in a national antislavery society and instituted competing abolitionist petitions to the king. The scale of the petitions was very modest: the Liberal petition acquired 125 signatures, the Orthodox Protestant one 56. The Rotterdam women were able to gather signatures of 128 women. Despite their modest numbers, the "utter novelty of this procedure here in this country" was widely discussed. Women had signed mixed petitions before and had petitioned for matters of personal interest, but contemporaries could not recall an example of collective female petitioning on a public issue (Janse 2007: 62-70).

Willem II did not receive the petitions favorably. When one of the signatories, a liberal MP who presided over the Second Chamber of Parliament, presented the king with the Rotterdam Ladies' petition, he could tell that Willem II did not know what to think of it. The king remarked that he had never received a petition like this. His Secret Service had informed him that the Dutch antislavery activities were the result of the influence of "British and American Missionaries." The broader public likewise "considered [the abolitionists] to be the tools of England," and this is exactly why Dutch abolitionists avoided collaborating with the British community in Rotterdam or organizing large-scale petitions: they did not want to behave in a "British" manner to avoid suspicion (and perhaps that cautious approach is part of the reason slavery was abolished in the Dutch colonies only in 1863). It has been recently argued that 
British attempts to shape continental political practices on the British model proved counterproductive: in France and the Netherlands abolitionists actively avoided making use of the "British apparatus" (Janse 2015). However, outsiders such as women (who were not allowed to join the Netherlands Society for the Promotion of the Abolition of Slavery [1853-63]) were perhaps more willing to organize petition campaigns. For example, in 1855, 733 Amsterdam women, many from working-class backgrounds, signed an antislavery petition addressed to the king (ibid.; Janse 2007: 109-11).

That same year, the temperance movement started a petition campaign for the prohibition of alcohol along the lines of the Maine law in the United States. This resulted in 170 petitions to Parliament. Prohibition was never introduced, but 25 years later, a Licensing Law for hard liquor was introduced, supported by 48,000 signatures. Petitioning practices in these decades changed in the sense that the petition was used increasingly to publicize good causes and gain new supporters, rather than to get those already convinced to sign (Janse 2007: 144; Talsma 1989: 295-96). When compared to other protest forms, such as participating in demonstrations or becoming a member of a pressure group, signing a petition demanded less commitment in terms of time or money. Charles Tilly observed that the emerging social movements of the early nineteenth century attempted to organize displays of worthiness, unity, numbers, and commitment (Tilly 2005). Following this, one could say that the petition campaign scored very high on unity (especially when the same petition text was signed) and on numbers (perhaps its most attractive feature), while it required only a limited amount of commitment. It was more complicated when it came to worthiness. Compared to a protest march, which was hardly regarded as respectable or legitimate behavior for most of the century, a petitionnement was perhaps the better option. Still, reformers worried whether petition campaigns would not discredit their organizations.

Several single-issue organizations debated this question: Was petitioning a legitimate and expedient means of furthering their goals? To give one example: in the 1860s the board of the Society for the Benefit of the Javanese (1866-77), which aimed at abolishing the cultivation system through which colonial subjects were exploited, proposed to petition Parliament. Members of the organization opposed this proposal, as did the liberal Minister of Colonial Affairs Fransen van de Putte, who was a member. He argued that, instead of petitioning, the society should focus on influencing public opinion through their lectures and journal. Many members felt a petition could discredit their cause "because it would be a political demonstration" (Janse 2007: 199-200).

The remark is revealing of wider tensions in Dutch political culture. Petitions were welcomed as expressions of public opinion, or even of the voice of the people. Nonvoters had the right to petition too, to express social grievances or moral concerns, for instance. But the people were not supposed to participate in politics as such. Society Chairman Willem Bosch defended petitioning: it was not a political demonstration, but a religious and humanitarian-inspired protest directed at politics. This debate formed part of a broader, heated debate within this and other reform 
societies over the question whether their organization was political or moral in nature. When in the second half of the nineteenth century more people were mobilized by moral issues with obvious political aspects, the lines between the two blurred, and the definition of politics eventually expanded to include moral protests by single-issue organizations (ibid.: 198-210).

In 1872, as part of the School Struggle, Orthodox Protestants established an Anti-Education Law League, after the example of the British Anti-Corn Law League and the Anti-Slavery Society, and most likely also inspired by the recent success of the Dutch Anti-Newspaper-Stamp League (Houkes 2009: 212; Janse 2005, 2007: 211-50). The Anti-Education Law League offered an important new perspective on petitioning: their petitions would not respond to Parliament's agenda, but were meant to set that agenda-based on the legitimacy of numbers. When the league reached 10,000 members, its leaders promised it would organize a petition campaign. In their conception of politics, the masses participated in legislative politics on the basis of their numbers, and from their own convictions and ideals. Even Groen, who had been an advocate of agitation for decades, could not condone this type of rhetoric. Shortly before his death, he attacked the leaders of the league for getting "carried away." Repeating a criticism he had often received when experimenting with innovative ways to include more people in the political process, he told them: "We are not in England" (Houkes 2009: 212-14).

\section{The "People's Petitionnement" of 1878}

However, a few years later an unprecedented mass petition suggested Dutch political culture was growing closer to that of Britain. It was organized against the liberal Education Law of 1877 that demanded higher standards from all schools, while restricting subsidies to state schools. The campaign was not organized by the AntiEducation Law League, but originated from the same Orthodox Protestant network. Unlike the Aprilbeweging, this petition campaign was something of which Orthodox Protestants would remain proud. The 1850 s petition campaigns were presented as spontaneous expressions of the people's will, merely facilitated by the church or voluntary associations. Now it almost seemed as if the petition was secondary and the display of organizing power its main feat. As part of the campaign, only months after the petition was presented to the king, an impressive, 167-page, illustrated "Memorial Book of the People's Petitionnement" was published (Feringa 1878).

The petition campaign was impressive by all accounts. The very day the law had passed both chambers of Parliament, its machinery was set in motion. A staggering 200,000 copies of the petition were spread across the country. A dense network of local committees and agents, directed by an efficient central committee, went on to gather 305,596 signatures in just one week. Catholics, who felt similar qualms about Kappeyne's Education Law, added a further 164,000 signatures of heads of households to this number. The Catholics had earlier sent petitions to the Second Chamber and the Senate, signed by 148,000 and 168,000 heads of households, respectively. 
This was truly a mass petitionnement: in total almost 800,000 signatures were contained in the Anti-Education Law petitions (De Bruijn 2011; De Coninck 2005: 310-12; Houkes 2009: 218-29).

More explicitly than ever before, this mass petition articulated the argument that it represented the popular will better than government or Parliament. Almost half a million people out of a total population of 4 million signed the petition, far more than the total number of eligible voters for parliamentary elections, which was only 122,000 . The petitioners even claimed that many more, "at least half of the people," agreed with them but had not signed because some disliked the means of petitionnement, while others, "despondent after twenty-five years of fruitless struggle, reckoned that this attempt would be without consequences as well" (Feringa 1878: 121).

In his official report on the petition, the Minister of Justice Jan Kappeyne van de Coppello stated that the "people's petitionnement should be qualified as a purely political demonstration, long in advance conceived and prepared." Why did they protest against the measure only once it had been debated and passed in Parliament, and not before? The people's petitionnement, he claimed, was not a moral campaign but rather a "[p]olitical movement, which tried to bring the king into conflict with the Representation" (ibid.: 136, 139, also see ibid.: 148).

The people's petitionnement leader Abraham Kuyper rejected Kappeyne's comment as an "outright falsehood." They had petitioned the king for another reason. "The general opinion was, that they should not go to Parliament, because it only aims to please the voters, and not the people, but only the voters, who can look after themselves." What, Kuyper asked, had the "so-called popular leaders" done? "What else, but to organize the popular expression [volksuiting], and inform the people, we dare say, in the most impartial manner" (ibid.: 158, 159)?

However, it cannot be denied that Kuyper had waged a months-long highly agitated press campaign to muster support for the petition. His rhetoric was indeed incendiary, antiparliamentary, and anticonstitutional at times. As Parliament represented only a liberal "voters' aristocracy," not the nation, the king should bypass Parliament and personally interfere in matters of state. Kuyper based his argument on the idea that freedom of conscience should also apply to the king. If liberals should force him to sign the law against his will, this would only prove the system was rotten. "Down with such immoral constitution! Down with such inconceivable system!” (De Bruijn 2011: 34-35).

Liberals were quick to condemn the petitionnement as the product of a "heap of people, goaded by deceitful mottos"; "the whipping up of passions"; "popular excitement through popular deceit"; and "senseless agitation, aroused by egotistical and fanatical leaders." A liberal newspaper vehemently denied that this was a "people's petitionnement," as it was nothing more than the expression of an ecclesiastical party, thus "lacking all national character." The Education Law, liberals argued, was meant to create national unity, and giving in to sectarianism would pose a severe threat to that ideal (De Coninck 2005: 311-12). Liberals argued that the scale of the signatures on the petitions came at the expense of quality. "When a tenth of this mass of petitioners would have signed, this manifestation could have been taken as 
sincere. $10,000,20,000$ or even 30,000 fearful people who struggle with their conscience would have been credible, but when the collectors came walking in with 100,000, 200,000 and 300,000 of ditto consciences, the effect was gone." The power of numbers was undermined by pointing out that high numbers necessarily implied low-quality petitions that were the product of insincere, manipulated political demonstrations (Houkes 2009: 226-27).

Willem III received the Orthodox Protestant petition sympathetically (Feringa 1878: 31), but he signed the Education Law nevertheless. Still, it had an important effect on the politicization, mobilization, and confidence of Orthodox Protestants. The organizers sensed the opportunity when they asked: "What do you do now with those hundreds of thousands, with the committees? ... Can something permanent, something good come out of it?" (De Bruijn 2011: 40). The petition campaign was important in the process of connecting religious identity to politics. Even if the role of the petitionnement in the process remains a matter of debate (Houkes 2009: 228-230; Janssens 2001: 146-55), it was a crucial step toward establishing the first political party in the Netherlands in 1879: the Anti-Revolutionary Party (De Bruijn 2011; Koch 2006: 186-90).

\section{Conclusion}

The political practices of the nineteenth-century Netherlands were embedded in a transnational context, in which Britain formed the most important example-or counterexample. But where in Britain and other countries mass petitioning was associated with progressive or reform causes such as antislavery, in the Netherlands the practice was most prominently used by conservative or antireform groups. After the 1830s, antirevolutionaries, rather than radicals, posed a greater challenge to the state by questioning the legitimacy of Parliament's representation of the people.

Organizing a large-scale petition campaign was not attempted very often in the nineteenth century. Several reform organizations hesitated to do so because they believed that their demands would be regarded as more legitimate if they abstained from politics. Politics in this sense referred to power politics between rivaling political factions, as played out in elections. Some critics abhorred the petitionnement as they understood it as an attempt at intimidation, inappropriate and illegitimate, and infringing the independence of the MPs. As the idea that nonvoters should not participate in politics was widely accepted, antirevolutionary attempts to mobilize "the people behind the voters" was considered close to revolutionary in the 1850s, echoing sentiments reinforced by the Belgian revolution of 1830. A petitionnement could both be a machine de guerre against a political faction, or a dangerous attempt at mixing popular passions - often religious - with politics.

Mass petitions necessarily challenged the political system, whose legitimacy was based on elections under a limited franchise. Petitions were a constant reminder that "the people" in the broader sense was much wider than the electorate from which 
Parliament derived its authority. Petitions not only asked for something but also gave something in return: recognition that the addressee would be receptive to the voice of the people, and thus represented them politically. Petitions, then, could question the legitimacy of Parliament, but also acknowledge it. In a system that was not based on popular sovereignty this still meant something - it could, as we have seen, shift the balance of power between different political authorities, especially the king and Parliament, when that balance had not been properly established.

During a transitional phase in Dutch politics, most MPs and upper-middle-class citizens envisioned the ideal petition as striking a balance between quality and quantity. A successful petition campaign would have a relatively large number such as 10,000, of high-quality signatures, meaning only those of well-informed, educated, independent, and respectable people - roughly the same criteria for being able to vote. Petitions with 10 or 20 times as many signatures by definition consisted of uninformed and less independent signatories, which decreased their impact and changed the petitions into a dangerous attempt to illegitimately influence politics and rouse the masses, risking undesirable outcomes, such as democracy.

The context is crucial to understanding the response of politicians, which were frequently flexible, or even opportunistic, depending on what they had to gain or lose. Liberals in the second quarter of the century defended large-scale petitions, to weaken the king's position and strengthen Parliament. When the Aprilbeweging instead strengthened the king's position vis-à-vis the cabinet, liberals denounced these petitions as lacking legitimacy. Antirevolutionaries supported and organized mass petitions when their position in Parliament was weak, and they saw extraparliamentary agitation of the "people behind the voters" as the main source of counterbalancing that weakness. The new political practices such as organizing single-issue organizations and petition campaigns, and the new emotional political style that developed out of agitation increasingly connected debates inside to those outside of Parliament, eventually leading to the first political party in 1879. Based on the same mechanisms seen in petition campaigns, the Orthodox Protestants, and later the Catholics and Socialists, successfully mobilized new groups, who effectively challenged liberal hegemony.

\section{Supplementary Material}

To view supplementary material for this article, please visit https://doi.org/10.1017/ ssh.2019.18

\section{References}

Aerts, R. A. M. (1997) De letterheren: liberale cultuur in de negentiende eeuw: het tijdschrift De Gids. Amsterdam, The Netherlands: Meulenhoff.

Aerts, R. A. M. (2018) Thorbecke wil het: biografie van een staatsman. Amsterdam, The Netherlands: Bert Bakker. 
Anon. (1830) Nederland, Monarchie en Christenstaat, of Opwekking tot Nederlandschen volksgeest en burgerzin. 's-Gravenhage, The Netherlands: G. Vervloet.

Anon. (1845) Nu of nooit: een ernstig woord aan alle gezeten burgers van Nederland. Dordrecht, The Netherlands: Blussé en Van Braam.

Arnhemsche Courant (1856), April 23.

Assen, Cornelis Jacobus van (1829) Het onwettige der petitiën aan de Staten-Generaal, of Geschied-en regtskundige uitlegging van art. 161 der Grondwet. Leiden, The Netherlands: C. C. van der Hoek.

Bruijn, Jan de (2011) "Weg met zóó onzedelijke constitutie!' Abraham Kuyper, volkspetitionnement en spoorwegstaking," in Jan de Bruijn (ed.) De sabel van Colijn: Biografische opstellen over religie en politiek in Nederland. Hilversum, The Netherlands: Verloren: 33-50.

Carpenter, Daniel, and Nicole Topich (2015) "Contested Boundaries of Representation: Patterns of Transformation in Black Petitioning in Massachusetts, 1770-1860," in Emmanuelle Avril and Johann N. Neem (eds.) Democracy, Participation and Contestation: Civil Society, Governance and the Future of Liberal Democracy. New York: Routledge: 201-22.

Colenbrander, H. T. (1905) Gedenkstukken der algemeene geschiedenis van Nederland van 1795 tot 1840. Part 9, Vol. II. 's-Gravenhage, The Netherlands: Nijhoff.

Coninck, Pieter de (2005) Een les uit Pruisen: Nederland en de Kulturkampf, 1870-1880. Hilversum, The Netherlands: Verloren.

Feringa, N. M. (1878) Gedenkboek betreffende het volkspetitionnement. Amsterdam, The Netherlands: Kruyt.

François, L. (1992) "De petitiebeweging in het Verenigd Koninkrijk der Nederlanden: balans van het onderzoek," in Coen A. Tamse and Els Witte (eds.) Staats-en natievorming in Willem I's Koninkrijk (1815-1830). Brussels, Belgium: VUB Press: 122-70.

Gelrus, Anonymus (1830) Waarschuwingen, opwekkingen en wenken, met betrekking tot den tegenwoordigen toestand van ons vaderland, inzonderheid ten aanzien van de ingediende petitiën, ter Tweede Kamer der heeren Staten-Generaal. Amsterdam, The Netherlands: Beijerinck.

Groen van Prinsterer, G. (1856a) De Tweede Kamer en de verzoekschriften, of De beraadslaging van 28 April 1856 met bijlagen en aanteekeningen toegelicht. Utrecht, The Netherlands: Kemink.

Groen van Prinsterer, G. (1856b) Aan de Kiezers, part viii. Utrecht, The Netherlands: Kemink.

Handelingen van de Tweede Kamer der Staten-Generaal. www.statengeneraaldigitaal.nl, accessed 13-04-2016.

Hodacs, Hanna (2003) "Converging World Views: The European Expansion and Early-NineteenthCentury Anglo-Swedish Contacts." Uppsala, Sweden: Uppsala Universitet.

Houkes, Annemarie (2002) "Het succes van 1848. Politiek in de Aprilbeweging," in G. N. M. Vis and W. Janse (eds.) Staf en storm: het herstel van de bisschoppelijke hiërarchie in Nederland in 1853: actie en reactie. Hilversum, The Netherlands: Verloren: 87-104.

Houkes, Annemarie (2009) Christelijke vaderlanders: godsdienst, burgerschap en de Nederlandse natie 1850-1900. Amsterdam, The Netherlands: Wereldbibliotheek.

Jaffe, James Alan (2019) "Languages of Petitioning in Colonial India (1780-1830)." Social Science History 43 (3): 581-97.

Janse, Maartje (2005). "Foreign Examples as Eye Openers and Justification: The Transfer of the Anti-Corn Law League and the Anti-Prostitution Movement to the Netherlands." European Review of History (12): 321-44.

Janse, Maartje (2007) De afschaffers: Publieke opinie, organisatie en politiek in Nederland 1840-1880. Amsterdam, The Netherlands: Wereldbibliotheek.

Janse, Maartje (2011) "Op de grens tussen staat en civil society: Samenwerking tussen hervormers en politici, 1840-1880." De Negentiende Eeuw 35 (4): 169-87.

Janse, Maartje (2015) “'Holland as a Little England'? British Anti-Slavery Missionaries and Continental Abolitionist Movements in the Mid Nineteenth Century." Past and Present 229 (1): 123-60.

Janse, Maartje, and Henk te Velde (2017) “Introduction: Perspectives on Political Organizing," in Maartje Janse and Henk te Velde (eds.) Organizing Democracy: Reflections on the Rise of Political Organizations in the 19th Century. Basingstoke, UK: Palgrave Macmillan: 1-18. 
Janssens, Rienk (2001) De opbouw van de Antirevolutionaire Partij, 1850-1888. Hilversum, The Netherlands: Verloren.

Koch, Jeroen (2006) Abraham Kuyper: een biografie. Amsterdam, The Netherlands: Boom.

Koch, Jeroen (2013) Koning Willem I: 1772-1843. Amsterdam, The Netherlands: Boom.

Kompagnie, J. H. (1985) “'Tekenend de kleine luiden . . ' Een protestactie van 215.000 ingezetenen anno 1797." Gens Nostra (40): 291-94.

Koorders, Daniel (1854) "De Aprilbeweging." De Gids (18): 1-41, 328-68, 595-667.

Manin, Bernard (1997) The Principles of Representative Government. Cambridge: Cambridge University Press.

McDaniel, W. Caleb (2013) The Problem of Democracy in the Age of Slavery: Garrisonian Abolitionists and Transatlantic Reform. Baton Rouge: Louisiana State University Press.

Meulen, Dik van der (2013) Koning Willem III: 1817-1890. Amsterdam, The Netherlands: Boom.

Miller, Henry (2017) "Petition! Petition!! Petition!!! Petitioning and Political Organization in Britain, c. 1800-1850," in Maartje Janse and Henk te Velde (eds.) Organizing Democracy: Reflections on the Rise of Political Organizations in the Nineteenth Century. Basingstoke, UK: Palgrave Macmillan: 43-61.

Oddens, Joris (2017) "The Greatest Right of Them All: The Debate on the Right to Petition in the Netherlands from the Dutch Republic to the Kingdom (c. 1750-1830)." European History Quarterly (47): 634-56.

Oddens, Joris, and Jouke Turpijn (2010) "Waarheid en gezond verstand in het Nederlandse parlement rondom 1798 en 1848." Jaarboek Parlementaire Geschiedenis: 23-35.

O'Ferrall, Fergus (1985) Catholic Emancipation: Daniel O'Connell and the Birth of Irish Democracy, 1820-30. Dublin: Gill and Macmillan.

Ouden, W. H. den (1994) Kerk onder patriottenbewind: kerkelijke financiën en de Bataafse Republiek, 1795-1801. Zoetermeer, The Netherlands: Boekencentrum.

Palacios Cerezales, Diego (2019) "Re-imagining Petitioning in Spain (1808-23)." Social Science History 43 (3): 487-508.

Ramakers, Emile (1990) "Een schuldig pligt-verzuim? Petitiebewegingen in Limburg tot herstel van grieven, 1828-1830," in B. C. M. van Hellenberg Hubar and P. J. H. Ubachs (eds.) Maaslands melange: opstellen over Limburgs verleden. Maastricht, The Netherlands: Limburgs Geschied- en Oudheidkundig Genootschap: 201-25.

Rooy, Piet de (2015) A Tiny Spot on the Earth: The Political Culture of the Netherlands in the Nineteenth and Twentieth Century. Amsterdam, The Netherlands: Wereldbibliotheek.

Santen, J. H. von (1979) "De Amstelsociëteit: liberale organisatie in Nederland in de jaren 1846-1851," in Wijnand Mijnhardt (ed.) Figuren en figuraties: acht opstellen aangeboden aan J. C. Boogman. Groningen, The Netherlands: Wolters-Noordhoff: 113-54.

Sas, N. C. F. van ([1982] 2004) "Het politiek klimaat in Noord-Nederland tijdens de crisis van het Verenigd Koninkrijk, 1828-1830," in N. C. F. van Sas (ed.) De metamorfose van Nederland: van oude orde naar moderniteit, 1750-1900. Amsterdam, The Netherlands: Amsterdam University Press: 437-55.

Sas, N. C. F. van ([1998] 2004) "Onder waarborging eener wijze constitutie. Grondwet en politiek, 1813-1848," in N. C. F. van Sas (ed.) De metamorfose van Nederland: van oude orde naar moderniteit, 1750-1900. Amsterdam, The Netherlands: Amsterdam University Press: 459-80.

Talsma, Jaap (1979) "Geeft met verschuldigde eerbied te kennen: petities over kiesstelsel en kiesrecht uit de periode 1848-1850." Tijdschrift voor Geschiedenis (92): 438-51.

Talsma, Jaap (1989) Vijf historische en rechtshistorische studies over het recht van petitie, verzoekschriften aan de Tweede Kamer en het ombudsmanvraagstuk: Nederland, 1795-1983. Arnhem, The Netherlands: Gouda Quint.

Thorbecke, J. R. ([1844] 1872) Historische schetsen. 's Gravenhage, The Netherlands: Nijhoff.

Tilly, Charles (2005) "Introduction to Part II: Invention, Diffusion, and Transformation of the Social Movement Repertoire." European Review of History (12): 307-20.

Velde, Henk te (2002) Stijlen van leiderschap: persoon en politiek van Thorbecke tot Den Uyl. Amsterdam, The Netherlands: Wereldbibliotheek. 
Velzen, P. L. G. van (2005) "De ongekende ministeriële verantwoordelijkheid, theorie en praktijk: 1813-1840." Nijmegen, The Netherlands: WLP.

Zanten, Jeroen van (2004) Schielijk, winzucht, zwaarhoofd en bedaard: politieke discussie en oppositievorming, 1813-1840. Amsterdam, The Netherlands: Wereldbibliotheek.

Zanten, Jeroen van (2013) Koning Willem II: 1792-1849. Amsterdam, The Netherlands: Boom. 